\title{
The Effect of Sn Addition on a Pt/C Electrocatalyst Synthesized by Borohydride Reduction and Hydrothermal Treatment for a Low-Temperature Fuel Cell
}

\author{
Dong-Ha Lim, ${ }^{\mathrm{a}, *}$ Dong-Hyeok Choi, ${ }^{\mathrm{a}}$ Weon-Doo Lee, ${ }^{\mathrm{a}}$ Dal-Ryung Park, ${ }^{\mathrm{b}}$ and \\ Ho-In Lee ${ }^{\mathrm{a}, \mathrm{z}}$ \\ ${ }^{a}$ School of Chemical and Biological Engineering and Research Center for Energy Conversion and Storage, \\ Seoul National University, Gwanak-gu, Seoul 151-744, Korea \\ ${ }^{b}$ Center for Gas Utilization Technology, KOGAS Research and Development Center, Ansan, Kyunggi-do \\ 425-150, Korea
}

\begin{abstract}
A 3Pt $1 \mathrm{Sn} / \mathrm{C}$ catalyst was readily synthesized by borohydride reduction and hydrothermal treatment for the anode electrode of a low-temperature fuel cell. The physical and electrochemical characterization of the $3 \mathrm{Pt} 1 \mathrm{Sn} / \mathrm{C}$ catalyst was performed by transmission electron microscopy (TEM), X-ray diffraction, $\mathrm{H}_{2}$ adsorption-desorption, methanol oxidation, and $\mathrm{CO}$ stripping. In the TEM image, the PtSn nanoparticles were uniformly well-dispersed on the carbon support with an average particle size of around $2.4 \mathrm{~nm}$. The 3Pt1Sn/C catalyst showed higher activity than commercial catalysts, and its onset potential for methanol oxidation was lower, possibly due to the electronic interaction between Pt and Sn and the increase of Pt lattice parameter. (C) 2007 The Electrochemical Society. [DOI: 10.1149/1.2710182] All rights reserved.
\end{abstract}

Manuscript submitted October 9, 2006; revised manuscript received December 26, 2006.

Available electronically February 22, 2007.

The most suitable electrocatalyst for a low-temperature fuel cells is Pt metal supported on carbon. However, $\mathrm{Pt}$, which is expensive and whose usage is therefore restrictive, is not the best catalyst for the anode material due to its easy poisoning by the strongly adsorbed CO. It is well known that methanol oxidation on a Pt catalyst produces $\mathrm{CO}$ as an intermediate, which is adsorbed on the active sites, resulting in their poisoning. ${ }^{1}$ To decrease the amount of $\mathrm{Pt}$ and to overcome the problem of $\mathrm{CO}$ poisoning, much effort has been made worldwide. One solution is to use secondary metals such as $\mathrm{Ru}^{2-4} \mathrm{Sn},{ }^{5-9} \mathrm{Mo},{ }^{10,11}$ and $\mathrm{Cr}^{12}$ to enhance the activity for the oxidation of methanol and promote the oxidation of the chemisorbed $\mathrm{CO}{ }^{13}$ Among these different possibilities, PtRu alloy is one of the most active catalysts and has been studied by many groups. ${ }^{2-4,14-16}$ $\mathrm{Ru}$ forms an oxygenated species at lower potentials than $\mathrm{Pt}$, and its presence promotes the oxidation of adsorbed $\mathrm{CO}$ to $\mathrm{CO}_{2}$ through a bifunctional mechanism. ${ }^{14-16}$ Recently, PtSn/C catalyst, which has been studied for the oxidation of methanol and ethanol, was used to promote the oxidation of both methanol and $\mathrm{CO}$ chemisorbed on the Pt sites. ${ }^{5,6,17-20}$ In previous works, PtSn/C catalyst synthesized by an impregnation and modified polyol method showed much higher activity than Pt/C catalyst. ${ }^{17,21,22}$ In this study, a $20 \mathrm{wt} \% 3 \mathrm{Pt} 1 \mathrm{Sn} / \mathrm{C}$ catalyst was synthesized by borohydride reduction and hydrothermal treatment for use as the anode electrode of a low-temperature fuel cell. The catalyst was characterized using X-ray diffraction (XRD), high-resolution transmission electron microscopy (HRTEM), and cyclic voltammetry.

\section{Experimental}

The $20 \mathrm{wt} \% \mathrm{PtSn} / \mathrm{C}$ catalyst with an atomic ratio of $\mathrm{Pt} / \mathrm{Sn}$ $=3: 1$ was prepared by borohydride reduction and subsequent hydrothermal treatment. This catalyst was named as $3 \mathrm{Pt} 1 \mathrm{Sn} / \mathrm{C}$ in this study. The preparation procedure was as follows: $0.022 \mathrm{~g}$ of chloroplatinic acid $\left(\mathrm{H}_{2} \mathrm{PtCl}_{6} \cdot 6 \mathrm{H}_{2} \mathrm{O}\right.$, Acros Organics), $0.0032 \mathrm{~g}$ of stannous chloride dehydrate $\left(\mathrm{SnCl}_{2} \cdot 2 \mathrm{H}_{2} \mathrm{O}\right.$, Junsei Chemicals), and $0.04 \mathrm{~g}$ of pretreated carbon black (Vulcan XC-72R, Cabot Co.) were quantitatively dissolved into $100 \mathrm{~mL}$ of distilled water and methanol in a Teflon bottle, and then $\mathrm{NaOH}$ was slowly added until the $\mathrm{pH}$ reached 11. Under vigorous stirring, $0.01 \mathrm{~g}$ of sodium borohydride $\left(\mathrm{NaBH}_{4}\right.$, Junsei Chemicals) in $50 \mathrm{~mL}$ of $\mathrm{H}_{2} \mathrm{O}$ was added dropwise to the solution, whereupon the color of the solution immediately turned dark black. The Teflon bottle was held in a stainless steel

* Electrochemical Society Student Member.

z E-mail: hilee@snu.ac.kr vessel and sealed tightly. The hydrothermal treatment was performed at $150^{\circ} \mathrm{C}$ for $3 \mathrm{~h}$ in an oven, after which the autoclave was cooled to room temperature and $\mathrm{HCl}$ added until the $\mathrm{pH}$ was 2 . The resultant suspension was filtered, washed with excess amounts of ethanol and distilled water, and dried in a vacuum oven at room temperature overnight. The hydrothermal process employs a high temperature and pressure to bring about the crystallization of $\mathrm{PtSn}$ alloy and $\mathrm{Sn}$ oxide. The activity of the $3 \mathrm{Pt} 1 \mathrm{Sn} / \mathrm{C}$ catalyst for methanol oxidation and its electrochemical active surface area (EAS) for $\mathrm{H}_{2}$ adsorption-desorption were evaluated. XRD, HRTEM, and cyclic voltammetry were employed to characterize the $3 \mathrm{Pt} 1 \mathrm{Sn} / \mathrm{C}$ catalyst.

The structural characteristics of the synthesized powders were investigated by XRD (Bruker, D8 ADVANCE) analysis using $\mathrm{Cu}$ $\mathrm{K} \alpha$ as a radiation source. The working voltage and current were maintained at $40 \mathrm{kV}$ and $30 \mathrm{~mA}$, respectively. The $2 \theta$ angular region between 20 and $80^{\circ}$ was explored at a scan rate of $1 \mathrm{deg} / \mathrm{step}$. The surface morphology of the PtSn nanoparticles on the surface of carbon black was studied by an HRTEM (JEOL, JEM-3010) operated at $300 \mathrm{kV}$. The TEM samples were prepared by adding a drop of a suspension, which was made by dispersing the catalyst in ethanol under ultrasonic condition, on a copper grid covered with carbon film, and then evaporating the ethanol.

Electrochemical measurements were carried out in a half-cell using a potentiostat (Gamry Instruments, PC4/750). The catalyst ink was prepared by mixing the catalyst particles with a $5 \%$ Nafion solution (DuPont, $1100 \mathrm{EW}$ ) and isopropyl alcohol (IPA) under ultrasonic conditions for about $30 \mathrm{~min}$ to form a slurry. The ratio of catalyst to Nafion in the catalyst ink was 3:1. A glassy carbon (GC) disk electrode (BAS, MF-2010) with a diameter of $6 \mathrm{~mm}$, which was polished to a mirror finish with a $0.05 \mu \mathrm{m}$ gamma alumina suspension (Buehler, 40-6301-016) before each experiment, was used as the substrate for the catalyst ink. A drop of catalyst ink was pipetted onto the surface of the GC disk electrode and dried at room temperature. Each electrode was installed into a three-electrode cell with a platinum mesh electrode (Princeton Applied Research, $219810)$ as the counter electrode and a $\mathrm{KCl}$ saturated $\mathrm{Ag} / \mathrm{AgCl}$ electrode (Bioanalytical System, Inc., MF-2052) as the reference electrode. The reference electrode was located as close as possible to the working electrode. The three-electrode cell was filled with the electrolyte solution and purged with nitrogen gas to remove the dissolved oxygen in the electrolyte solution. In this study, all of the potentials were recorded with respect to a normal hydrogen electrode (NHE). 


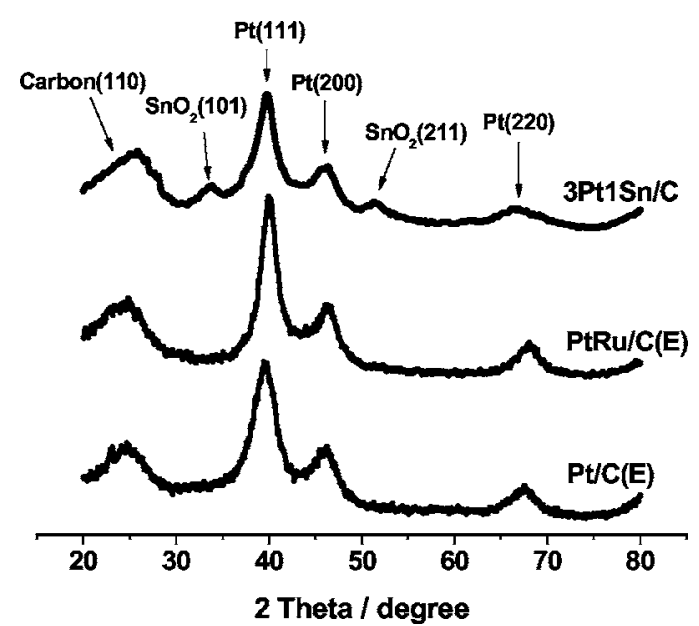

Figure 1. XRD patterns of the $3 \mathrm{Pt} 1 \mathrm{Sn} / \mathrm{C}, \mathrm{PtRu} / \mathrm{C}$, and $\mathrm{Pt} / \mathrm{C}$ catalysts.

\section{Results and Discussion}

The XRD patterns of the 3Pt1Sn/C catalyst synthesized by borohydride reduction and hydrothermal treatment are shown in Fig. 1. The patterns of the commercial PtRu/C and Pt/C catalysts (E-TEK) are also shown in the same figure for comparison. It is clearly seen from the diffraction pattern of $3 \mathrm{Pt} 1 \mathrm{Sn} / \mathrm{C}$ in Fig. 1 that both crystalline $\mathrm{Pt}$ phase and $\mathrm{SnO}_{2}$ phase exist. No obvious peaks for $\mathrm{Sn}$ are observed in Fig. 1. The Pt (220) peak of the 3Pt1Sn/C shifts slightly to a lower $2 \theta$ value compared with that of $\mathrm{Pt} / \mathrm{C}$, suggesting the formation of an alloy, which is caused by the interposition of $\mathrm{Sn}$ in the face-centered cubic (fcc) structure of Pt. The characterization results are also shown in Table I. The lattice parameter of the commercial PtRu/C catalyst after alloying is smaller than that of the commercial $\mathrm{Pt} / \mathrm{C}$ catalyst, while the lattice parameter of the $3 \mathrm{Pt} 1 \mathrm{Sn} / \mathrm{C}$ catalyst is larger than that of the commercial Pt/C catalyst due to lattice expansion after alloying between $\mathrm{Pt}$ and $\mathrm{Sn}$. The lattice parameter of the $3 \mathrm{Pt} 1 \mathrm{Sn} / \mathrm{C}$ catalyst synthesized by borohydride reduction and hydrothermal treatment is similar to that of the bulk 3Pt1Sn solid solution. ${ }^{19,23}$ Table I shows that the crystallite size of the $3 \mathrm{Pt} 1 \mathrm{Sn} / \mathrm{C}$ catalyst is smaller than those of the PtRu/C and Pt/C catalysts. The $3 \mathrm{Pt} 1 \mathrm{Sn} / \mathrm{C}$ catalyst has a crystallite size of around $2.5 \mathrm{~nm}$, as calculated from the width of the Pt (220) peak according to Scherrer's formula. ${ }^{24}$

In Fig. 2a it can be seen that 3Pt1Sn nanoparticles with a narrow particle size distribution are well-dispersed on the carbon support. The size distribution of 3Pt1Sn nanoparticles on the carbon support was obtained by measuring the sizes of 150 randomly chosen particles from a TEM image. The HR-TEM image of the 3Pt1Sn/C catalyst is shown in Fig. 2b, which shows that the 3Pt1Sn nanoparticles are dispersed on the edges of each grain of the carbon support and are uniform, with an average particle size of around $2.4 \mathrm{~nm}$, which is in good agreement with the XRD data. The good distribution of the 3Pt1Sn nanoparticles is known to be important for the catalytic activity. ${ }^{20}$ The 3Pt1Sn nanoparticles deposited on a carbon

Table I. The physical properties of the $3 \mathrm{Pt} 1 \mathrm{Sn} / \mathrm{C}$, commercial $\mathrm{PtRu} / \mathrm{C}$, and commercial Pt/C, calculated from the XRD data

\begin{tabular}{cccc} 
Sample & $\begin{array}{c}\text { Lattice } \\
\text { parameter } \\
(\mathrm{nm})\end{array}$ & $\begin{array}{c}\text { Pt surface area } \\
\left(\mathrm{m}^{2} / \mathrm{g}\right)\end{array}$ & $\begin{array}{c}\text { Crystallite } \\
\text { size } \\
(\mathrm{nm})\end{array}$ \\
\hline 3Pt1Sn/C & 0.3963 & 112 & 2.5 \\
$\mathrm{Pt} / \mathrm{C}(\mathrm{E})$ & 0.3917 & 87.4 & 3.2 \\
$\mathrm{PtRu} / \mathrm{C}(\mathrm{E})$ & 0.3881 & 77.7 & 3.6
\end{tabular}

(a)
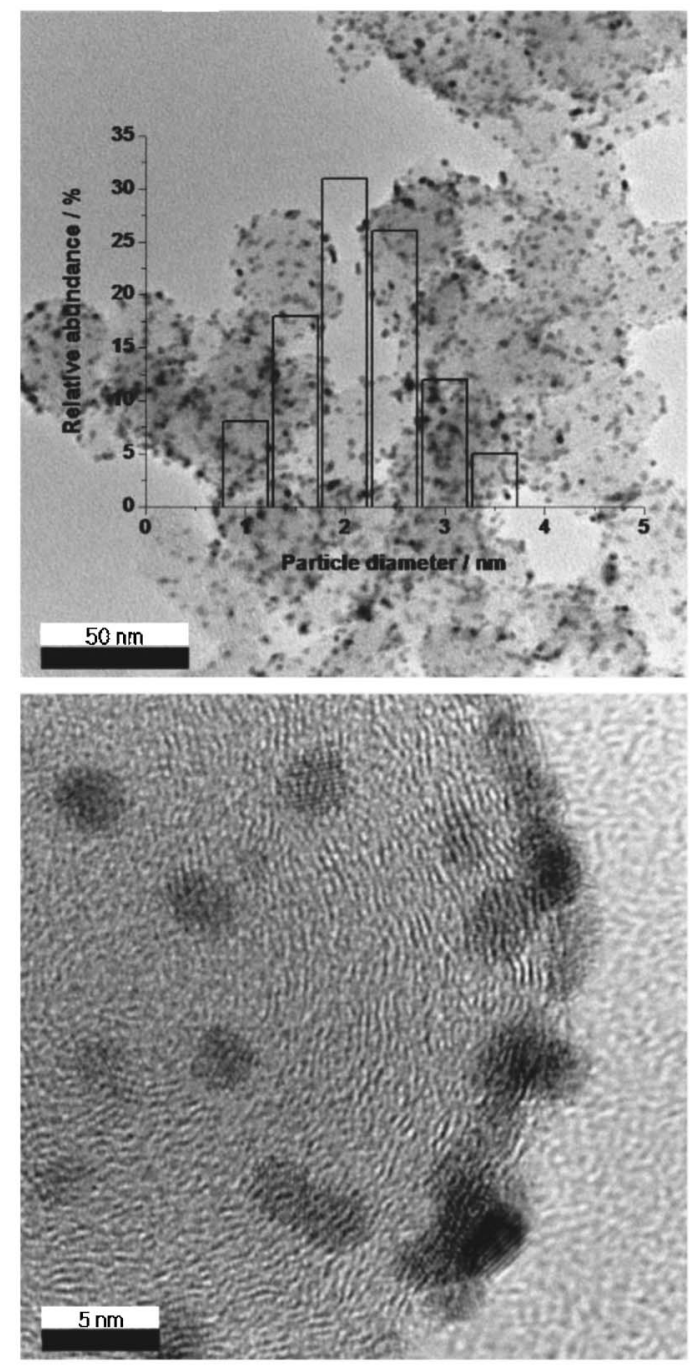

(b)

Figure 2. (a) TEM image and (b) HRTEM image of the $3 \mathrm{Pt} 1 \mathrm{Sn} / \mathrm{C}$ catalyst synthesized by borohydride reduction and hydrothermal treatment.

support, synthesized by borohydride reduction and hydrothermal treatment, are expected to have good catalytic activity and $\mathrm{CO}$ tolerance in the methanol oxidation.

For the measurement of the $\mathrm{H}_{2}$ adsorption-desorption curve, the potential was cycled between 0 and $1.2 \mathrm{~V}$ [vs a normal hydrogen electrode (NHE)] at $20 \mathrm{mV} / \mathrm{s}$ in a $0.5 \mathrm{M} \mathrm{H}_{2} \mathrm{SO}_{4}$ electrolyte solution purged with nitrogen at $25^{\circ} \mathrm{C}$. These curves were stabilized after ten cycle in the potential range. Figure 3 shows the $\mathrm{H}_{2}$ adsorptiondesorption curves of the $3 \mathrm{Pt} 1 \mathrm{Sn} / \mathrm{C}, \mathrm{PtRu} / \mathrm{C}$, and $\mathrm{Pt} / \mathrm{C}$ catalysts. These catalysts exhibit well-defined $\mathrm{H}_{2}$ adsorption-desorption peaks in the potential region of ca. 0 to $0.25 \mathrm{~V}$ (vs NHE) and the adsorption-desorption peaks of oxygen species at around $0.7 \mathrm{~V}$ and $1.0 \mathrm{~V}$ (vs NHE), which are in a good agreement with the literature values. ${ }^{25,26}$ The $3 \mathrm{Pt} 1 \mathrm{Sn} / \mathrm{C}$ and $\mathrm{PtRu} / \mathrm{C}$ catalysts show a much less distinct $\mathrm{H}_{2}$ adsorption-desorption region in comparison with $\mathrm{Pt} / \mathrm{C}$, due to the occurrence alloying between $\mathrm{Pt}$ and $\mathrm{Sn}$ (or Ru) ${ }^{27,28}$ The cyclic voltammogram curve of the $3 \mathrm{Pt} 1 \mathrm{Sn} / \mathrm{C}$ catalyst shows an increase in the current density at the double layer caused by the addition of Sn. ${ }^{27,28}$ It can be seen in Fig. 3 that small peaks appear at around 0.53 and $0.75 \mathrm{~V}$, which may be attributed to the adsorption and desorption of oxygen-containing species resulting from the dis- 


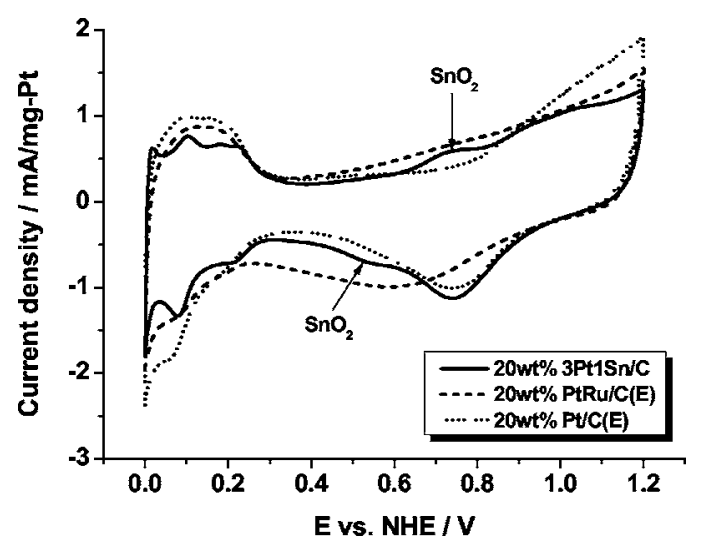

Figure 3. Cyclic voltammograms of $\mathrm{H}_{2}$ adsorption-desorption on the 3Pt1Sn/C, PtRu/C, and Pt/C catalysts.

sociation of water on $\mathrm{SnO}_{2}{ }^{5,6,29}$ This may be attributed to the presence of $\mathrm{SnO}_{2}$, as observed in the XRD patterns of Fig. 1, which plays a very important role in methanol oxidation and $\mathrm{CO}$ oxidation at low potentials. ${ }^{30}$

In order to check the activity of the catalyst for methanol oxidation, a mixed solution of $2 \mathrm{M} \mathrm{CH}_{3} \mathrm{OH}$ and $0.5 \mathrm{M} \mathrm{H}_{2} \mathrm{SO}_{4}$ purged with nitrogen at $40^{\circ} \mathrm{C}$ was used as the electrolyte solution. The current values were normalized by both the loading amount and the surface area of $\mathrm{Pt}$ metal, considering that methanol adsorption and dehydrogenation occur only on the $\mathrm{Pt}$ sites at room temperature. ${ }^{3,95,31-33}$ The mass- and area-normalized current densities were obtained as shown in Fig. 4. However, the current densities are generally normalized by the amount of loaded metal due to the economic efficiency. In Fig. 4, the mass- and area-normalized cur-
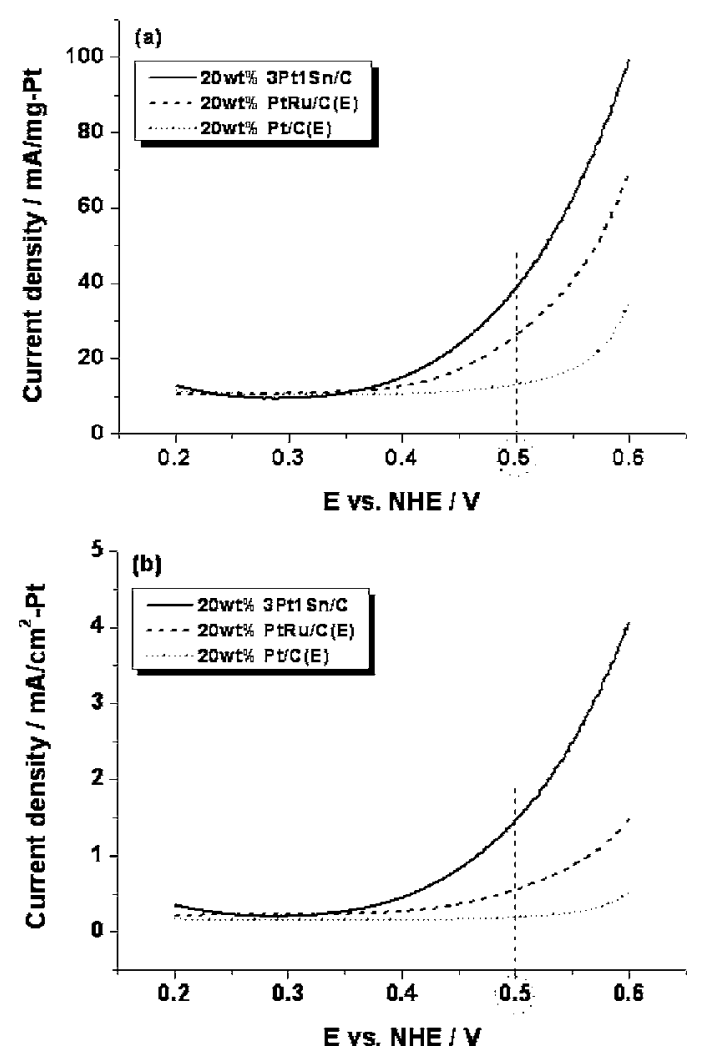

Figure 4. (a) Mass- and (b) area-normalized cyclic voltammograms of $\mathrm{MeOH}$ oxidation on the $3 \mathrm{Pt} 1 \mathrm{Sn} / \mathrm{C}, \mathrm{PtRu} / \mathrm{C}$, and $\mathrm{Pt} / \mathrm{C}$ catalysts.

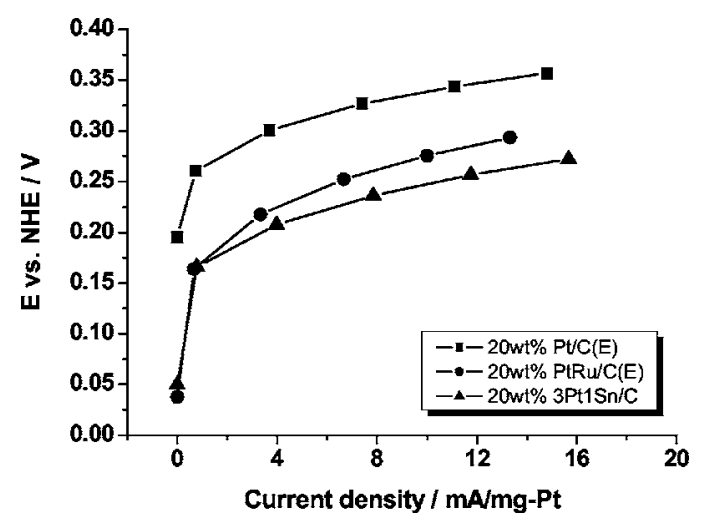

Figure 5. Galvanostatic polarization curves for the $3 \mathrm{Pt} 1 \mathrm{Sn} / \mathrm{C}, \mathrm{PtRu} / \mathrm{C}$, and $\mathrm{Pt} / \mathrm{C}$ catalysts obtained at $40^{\circ} \mathrm{C}$ in a mixed solution of $0.5 \mathrm{M} \mathrm{H}_{2} \mathrm{SO}_{4}$ and $2 \mathrm{M} \mathrm{MeOH}$.

rent densities of methanol oxidation on the $3 \mathrm{Pt} 1 \mathrm{Sn} / \mathrm{C}, \mathrm{PtRu} / \mathrm{C}$, and $\mathrm{Pt} / \mathrm{C}$ catalysts are shown. The $3 \mathrm{Pt} 1 \mathrm{Sn} / \mathrm{C}$ catalyst shows higher catalytic activity than the $\mathrm{PtRu} / \mathrm{C}$ and $\mathrm{Pt} / \mathrm{C}$ catalysts in both the cases. The current densities of methanol oxidation on the $3 \mathrm{Pt} 1 \mathrm{Sn} / \mathrm{C}$ and $\mathrm{PtRu} / \mathrm{C}$ catalysts sharply increase in the region of $0.4-0.5 \mathrm{~V}$ (vs NHE), while that on the $\mathrm{Pt} / \mathrm{C}$ catalyst slightly increases until $0.55 \mathrm{~V}$ (vs NHE). The area-normalized current densities were obtained by dividing the measured currents by the calculated electrochemical surface areas from the $\mathrm{CO}_{\mathrm{ad}}$ stripping test. The area-normalized current density represents the intrinsic activity of the active sites in the electrocatalysts. Because the mass-normalized current density represents the economic efficiency of the catalysts, however, it is generally adopted instead of the area-normalized one in case of similar catalytic environments resulting in the same qualitative trends. The 3Pt1Sn/C catalyst showed a same trend in order being compared with the $\mathrm{PtRu} / \mathrm{C}$ and $\mathrm{Pt} / \mathrm{C}$ catalysts between mass- and areanormalized current densities at $0.5 \mathrm{~V}$ (vs NHE), as shown in Fig. 4. The difference in gaps of the two defined current densities is due to the different metal dispersions.

According to the results shown in Fig. 4a, the onset potentials of methanol oxidation on the $3 \mathrm{Pt} 1 \mathrm{Sn} / \mathrm{C}, \mathrm{PtRu} / \mathrm{C}$, and $\mathrm{Pt} / \mathrm{C}$ catalysts are $0.32,0.35$, and $0.45 \mathrm{~V}$, respectively. The onset potential of methanol oxidation is lower on the $3 \mathrm{Pt} 1 \mathrm{Sn} / \mathrm{C}$ catalyst than on the $\mathrm{PtRu} / \mathrm{C}$ and $\mathrm{Pt} / \mathrm{C}$ catalysts. ${ }^{5,6,17}$ This indicates that the energy required for methanol oxidation on the $3 \mathrm{Pt} 1 \mathrm{Sn} / \mathrm{C}$ catalyst is lower, which may be attributed to both the electronic interaction between $\mathrm{Pt}$ and $\mathrm{Sn}$ and the changes in the Pt lattice parameter due to the addition of $\mathrm{Sn}^{30,34}$ The presence of alloyed Sn which expands the lattice allows methanol to adsorb and dissociate, thus allowing the $\mathrm{C}-\mathrm{H}$ bonds to be broken at lower potentials than that observed on the $\mathrm{PtRu} / \mathrm{C}$ and $\mathrm{Pt} / \mathrm{C}$ catalysts. ${ }^{17}$ Therefore, the $3 \mathrm{Pt} 1 \mathrm{Sn} / \mathrm{C}$ catalyst is thought to be a more suitable catalyst for methanol oxidation than the $\mathrm{PtRu} / \mathrm{C}$ and $\mathrm{Pt} / \mathrm{C}$ catalysts.

The galvanostatic polarization curves were obtained for the $3 \mathrm{Pt} 1 \mathrm{Sn} / \mathrm{C}, \mathrm{PtRu} / \mathrm{C}$, and $\mathrm{Pt} / \mathrm{C}$ catalysts at $40^{\circ} \mathrm{C}$ in a mixed solution of $0.5 \mathrm{M} \mathrm{H}_{2} \mathrm{SO}_{4}$ and $2 \mathrm{M} \mathrm{MeOH}$. The current is plotted at $\mathrm{mA} / \mathrm{mgPt}$ in Fig. 5 to ensure that the data are comparable. It can be seen from Fig. 5 that the $3 \mathrm{Pt} 1 \mathrm{Sn} / \mathrm{C}$ catalyst shows the best performance over the entire range of polarization. This result is consistent with the result of methanol oxidation presented in Fig. 4.

The activity of the 3Pt1Sn/C catalyst for $\mathrm{CO}$ oxidation was investigated by $\mathrm{CO}$ stripping voltammetry at $50 \mathrm{mV} / \mathrm{s}$, during which $\mathrm{CO}$ was adsorbed on the catalysts at $0.1 \mathrm{~V}$ (vs NHE) for $30 \mathrm{~min}$. The CO stripping voltammograms of the $3 \mathrm{Pt} 1 \mathrm{Sn} / \mathrm{C}, \mathrm{PtRu} / \mathrm{C}$, and $\mathrm{Pt} / \mathrm{C}$ catalysts are shown in Fig. 6. The onset potential of $\mathrm{CO}$ oxidation occurs at $0.39 \mathrm{~V}$ (vs NHE) for the PtRu/C catalyst and $0.71 \mathrm{~V}$ (vs NHE) for the Pt/C catalyst, whereas on the $3 \mathrm{Pt} 1 \mathrm{Sn} / \mathrm{C}$ catalyst, the onset potential of $\mathrm{CO}$ oxidation starts at $0.23 \mathrm{~V}$ (vs 


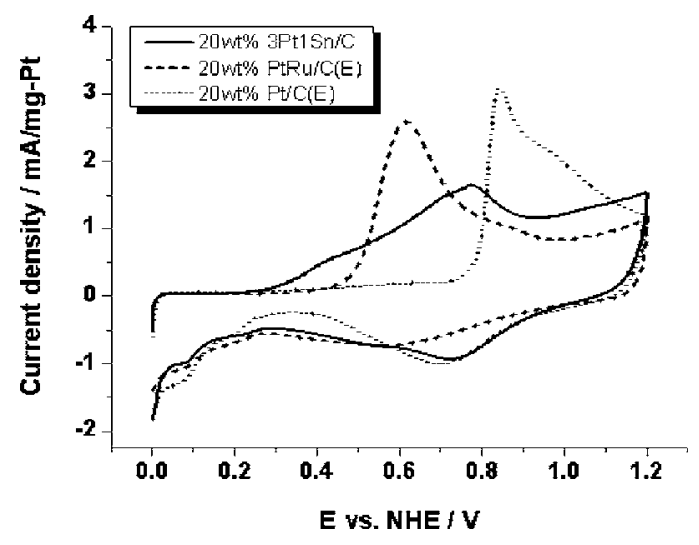

Figure 6. CO stripping voltammograms for the $3 \mathrm{Pt} 1 \mathrm{Sn} / \mathrm{C}$, PtRu/C, and $\mathrm{Pt} / \mathrm{C}$ catalysts obtained at room temperature with a scan rate of $50 \mathrm{mV} / \mathrm{s}$ in a $0.5 \mathrm{M} \mathrm{H}_{2} \mathrm{SO}_{4}$ solution.

NHE), showing a maximum peak at $0.76 \mathrm{~V}$ (vs NHE). This indicates that the activity of the $3 \mathrm{Pt} 1 \mathrm{Sn} / \mathrm{C}$ catalyst for $\mathrm{CO}$ oxidation is superior to those of the $\mathrm{PtRu} / \mathrm{C}$ and $\mathrm{Pt} / \mathrm{C}$ catalysts. It appears that $\mathrm{Sn}$ has the ability to promote the oxidation of adsorbed $\mathrm{CO}$ at low potentials. ${ }^{18}$ The shift of the onset potential on the $3 \mathrm{Pt} 1 \mathrm{Sn} / \mathrm{C}$ catalyst may be attributed to the presence of oxygenated species on the $\mathrm{Sn}$ sites at a lower potential as compared to the $\mathrm{PtRu} / \mathrm{C}$ and $\mathrm{Pt} / \mathrm{C}$ catalysts. ${ }^{18-20}$ The superior activity of the $3 \mathrm{Pt} 1 \mathrm{Sn} / \mathrm{C}$ catalyst can be explained by a bifunctional mechanism. $\mathrm{OH}$ adsorbed and formed by the dissociative adsorption of water onto the $\mathrm{Sn}$ or Sn oxide sites could oxidize the $\mathrm{CO}$ adsorbed onto $\mathrm{Pt}$ to $\mathrm{CO}_{2}$ at lower potentials. ${ }^{5,6}$ The shift of the onset potential to a lower value in the $\mathrm{CO}$ stripping voltammetry for the PtSn/C catalyst is in agreement with the findings previous works. ${ }^{5,6,17-20}$ Vigier et al. reported that $\mathrm{SnO}_{2}$ could supply oxygen species for the oxidation of $\mathrm{CO}$ adsorbed on the adjacent Pt sites, thereby enhancing the oxidation of ethanol at low potentials. ${ }^{35}$ Moreover, the range of potentials allowing for the oxidation of $\mathrm{CO}$ on the $3 \mathrm{Pt} 1 \mathrm{Sn} / \mathrm{C}$ catalyst is wider than those on the $\mathrm{PtRu} / \mathrm{C}$ and $\mathrm{Pt} / \mathrm{C}$ catalysts. According to Massong et al., ${ }^{36}$ this is due to the presence of adsorbed, linearly bonded $\mathrm{CO}$ and bridgebonded $\mathrm{CO}$ on the Pt sites. They claimed that the bridge-bonded $\mathrm{CO}$ could be oxidized at a lower potential on $\mathrm{PtSn} / \mathrm{C}$ than on $\mathrm{Pt} / \mathrm{C}$. Therefore, the addition of $\mathrm{Sn}$ is thought to prevent $\mathrm{CO}$ from poisoning the active Pt sites through the easier oxidation of adsorbed CO.

\section{Conclusions}

In conclusion, a $20 \mathrm{wt} \% 3 \mathrm{Pt} 1 \mathrm{Sn} / \mathrm{C}$ electrocatalyst was easily synthesized by borohydride reduction and hydrothermal treatment for use as the anode electrode of a low-temperature fuel cell. From both the XRD and HR-TEM results, it was found that the 3Pt1Sn/C nanoparticles were uniformly well dispersed on the carbon support with an average particle size of $2.4 \mathrm{~nm}$. The good distribution of the 3Pt1Sn nanoparticles is known to be an important factor in the catalytic activity. The 3Pt1Sn/C catalyst showed higher catalytic activity for methanol oxidation than the commercial catalysts. The catalytic activity for methanol oxidation was consistent with the galvanostatic polarization curves. The onset potential for methanol oxidation with the $3 \mathrm{Pt} 1 \mathrm{Sn} / \mathrm{C}$ catalyst was lower, which may be attributed to both the electronic interaction between $\mathrm{Pt}$ and $\mathrm{Sn}$ and the changes in the $\mathrm{Pt}$ lattice parameter due to the addition of $\mathrm{Sn}$. The oxidation of $\mathrm{CO}$ on the $3 \mathrm{Pt} 1 \mathrm{Sn} / \mathrm{C}$ catalyst occurred at a lower potential than that on the commercial catalysts. It appeared that Sn has the ability to pro- mote the oxidation of adsorbed $\mathrm{CO}$ at low potentials. The removal of the $\mathrm{CO}$ adsorbed onto $\mathrm{Pt}$ proceeded via its reaction with $\mathrm{OH}$ adsorbed onto the $\mathrm{Sn}$ or $\mathrm{Sn}$ oxide sites formed by the dissociative adsorption of water.

\section{Acknowledgments}

This work was financially supported by the Korea Gas Corporation, the Brain Korea 21 Project in 2005, and the ERC Program of MOST/KOSEF (grant no. R11-2002-102-00000-0).

Seoul National University assisted in meeting the publication costs of this article.

\section{References}

1. T. Iwasita, H. Hoster, A. John-Anaker, W. F. Lin, and W. Vielstich, Langmuir, 16, $522(2000)$.

2. J.-H. Choi, K.-W. Park, B.-K. Kwon, and Y.-E. Sung, J. Electrochem. Soc., 150, A973 (2003).

3. H. A. Gasteiger, N. Markovic, P. N. Ross, and E. J. Cairns, J. Electrochem. Soc., 141, 1795 (1994)

4. S.-A. Lee, K.-W. Park, B.-K. Kwon, and Y.-E. Sung, J. Ind. Eng. Chem. (Seoul, Repub. Korea), 9, 63 (2002).

5. M. Arenz, V. Stamenkovic, B. B. Blizanac, K. J. Mayrhofer, N. M. Markkovic, and P. N. Ross, J. Catal., 232, 402 (2005).

6. I. Honma and T. Toda, J. Electrochem. Soc., 150, A1689 (2003).

7. W. S. Cardoso, M. S. P. Francisco, A. M. S. Lucho, and Y. Gushiken, Solid State Ionics, 167, 165 (2004).

8. M. Gotz and H. Wendt, in Proton Conducting Membrane Fuel Cells II, S. Gottesfeld and T. F. Fuller, Editors, PV 98-27, p. 291, The Electrochemical Society Proceedings Series, Pennington, NJ (1999).

9. E. Peled, T. Duvdevani, A. Ahron, and A. Melman, Electrochem. Solid-State Lett., 4, A38 (2001).

10. M. Götz and H. Wendt, Electrochim. Acta, 43, 3637 (1998).

11. A. O. Neto, M. J. Giz, J. Perez, E. A. Ticianelli, and E. R. Gonzalez, J. Electrochem. Soc., 149, A272 (2002).

12. J.-S. Choi, W.-S. Chung, H.-Y. Ha, T.-H. Lim, I.-H. Oh, S.-A. Hong, and H.-I. Lee, J. Power Sources, 156, 466 (2006).

13. S. Ball, A. Hodgkinson, G. Hoogers, S. Maniguet, D. Thompsett, and B. Wong, Electrochem. Solid-State Lett., 5, A31 (2002).

14. W. Xu, T. Lu, C. Liu, and W. Xing, J. Phys. Chem., 109, 14325 (2005).

15. H. A. Gasteiger, N. M. Markovic, and P. N. Ross, Jr., J. Phys. Chem., 99, 8290 (1995).

16. K.-W. Park and Y.-E. Sung, J. Ind. Eng. Chem. (Seoul, Repub. Korea), 12, 165 (2006).

17. W. J. Zhou, B. Zhou, W. Z. Li, Z. H. Zhou, S. Q. Song, G. Q. Sun, Q. Xin, S. Douvartzides, M. Goula, and P. Tsiakaras, J. Power Sources, 126, 16 (2004).

18. E. M. Crabb, R. Marshall, and D. Thompsett, J. Electrochem. Soc., 147, 4440 (2000).

19. F. Colmati, E. Antolini, and E. R. Gonzalez, Electrochim. Acta, 50, 5496 (2005).

20. D.-Y. Lee, S.-W. Hwang, and I.-S. Lee, J. Power Sources, 145, 147 (2005).

21. L. Jiang, G. Sun, S. Sun, J. Liu, S. Tang, H. Li, B. Zhou, and Q. Xin, Electrochim. Acta, 50, 5384 (2005).

22. C. Lamy, S. Rousseau, E. M. Belgasir, C. Coutanceau, and J.-M. Leger, Electrochim. Acta, 49, 3901 (2004).

23. M. Hoheisel, S. Speller, J. Kuntze, A. Atrei, U. Bardi, and W. Heiland, Phys. Rev. $B, \mathbf{6 3}, 245403$ (2001)

24. V. Radmiloviae, H. A. Gasteiger, and P. N. Ross, Jr., J. Catal., 154, 98 (1995).

25. J. R. C. Salgado, E. Antolini, and E. R. Gonzalez, J. Power Sources, 138, 56 (2004).

26. N. M. Markovic, H. A. Gasteiger, P. N. Ross, Jr., X. Jiang, I. Villegas, and M. J. Weaver, Electrochim. Acta, 40, 91 (1995).

27. R. B. Lima, V. Paganin, T. Iwasita, and W. Vielstich, Electrochim. Acta, 49, 85 (2003).

28. E. V. Spinace, A. O. Neto, and M. Linardi, J. Power Sources, 129, 121 (2004).

29. T. Frelink, W. Visscher, and J. A. R. van Veen, Electrochim. Acta, 39, 1871 (1994)

30. S. Mukerjee and J. McBreen, J. Electrochem. Soc., 146, 600 (1999).

31. M. Christov and K. Sundmacher, Surf. Sci., 1, 547 (2003).

32. L. Dubau, F. Hahn, C. Countaceau, J.-M. Leger, and C. Lamy, J. Electroanal. Chem., 407, 554 (2003).

33. Y. Takasu, T. Fujiwara, Y. Murakami, K. Sasaki, M. Oguri, T. Asaki, and W. Sugimoto, J. Electrochem. Soc., 147, 4421 (2000).

34. A. O. Neto, T. R. R. Vasconcelos, R. W. R. V. Da Silva, M. Linardi, and E. V. Spinace, J. Appl. Electrochem., 35, 193 (2005).

35. F. Vigier, C. Coutanceau, F. Hahn, E. M. Belgsir, and C. Lamy, J. Electroanal. Chem., 563, 81 (2004).

36. H. Massong, H. Wang, G. Samjeske, and H. Baltruschat, Electrochim. Acta, 46, $701(2000)$ 